\title{
Reciprocal recurrent selection for obtaining water-deficit tolerant maize progeny
}

\author{
Fernanda Vargas Valadares ${ }^{1^{*}}$ (D) Rafael Nunes de Almeida ${ }^{1}$ (i) Lázaro Renilton Emerick Silva $^{2}$ (i) \\ Geferson Rocha Santos ${ }^{1}$ (i) Raissa Olmo Lacerda Pirovani ${ }^{2}$ (i) José Dias de Souza Neto ${ }^{2}$ (i) \\ Ana Paula Cândido Gabriel Berilli ${ }^{2}$ Monique Moreira Moulin² (D) Marcelo Vivas ${ }^{1}$ (D) \\ Sávio da Silva Berilli² ${ }^{2}$ Messias Gonzaga Pereira ${ }^{1}$ (i)
}

${ }^{1}$ Centro de Ciências e Tecnologias Agropecuárias, Universidade Estadual do Norte Fluminense Darcy Ribeiro (UENF), Avenida Alberto Lamego, 28013-602, Campos dos Goytacazes, RJ, Brasil. E-mail: fernanda_valladares@hotmail.com. *Corresponding author. ${ }^{2}$ Laboratório de Genética e Biologia Molecular, Instituto Federal do Espírito Santo (IFES), Alegre, ES, Brasil.

\begin{abstract}
In view of the need to increase genetic variability to obtain materials with a significant capacity to drought tolerance, this study conducted a cycle of a reciprocal recurrent selection of full-sib families of maize. To this end, 64 full-sib families of maize were evaluated in two environments according to their morpho-agronomic data in a randomized block design with two replicates. It were analyzed of Male flowering (MF); Female flowering (FF); Flowering interval (IF); days for flowering (DF); Plant height (PH); Ear height (EH); number of plants at the Stand (NPS); Number of broken plant (NBrP); Number of bedded plants (NBeP); Strawing (St); Ear length (EL); Ear diameter (ED); Ear number (EN); Prolificacy (Pr); Number of diseased ears (NDE); Number of ears attacked by pests (NEP); Ear weight (EW); Yield (YIE) and Total Chlorophyll Index (TCI). The analysis of variance was performed by the F test at $5 \%$ significance level, and also the evaluation of genetic parameters. Regarding morpho-agronomic data, the analysis of variance and the analysis of genetic parameters showed that there was no interaction genotype $x$ environment with regard to the genetic variability among the families under study. Lastly, the final selection of the superior genotypes was made on the basis of the ranking of the 40 most productive families, from which, combined with the molecular data, the 30 most productive, most drought-tolerant, and most genetically diverse ones were selected to compose the next cycle of recurrent maize selection aiming water-stress tolerance.

Key words: genetic diversity, interpopulation breeding, reciprocal recurrent selection, water stress.
\end{abstract}

Seleção recorrente recíproca para obtenção de progênies de milho tolerantes ao déficit hídrico

RESUMO: Tendo em vista a necessidade de aumentar a variabilidade genética para obter materiais com significativa capacidade de tolerância à seca, este estudo conduziu um ciclo de seleção recorrente recíproca de famílias de irmãos completos de milho. Para tanto, 64 famílias de irmãos completos de milho foram avaliadas em dois ambientes de acordo com seus dados morfoagronômicos em um delineamento de blocos casualizados com duas repetições. Foram analisados o florescimento masculino (MF); florescimento feminino (FF); Intervalo de florescimento (IF); dias para florescimento (DF); Altura da planta (PH); Altura da espiga (EH); número de plantas na parcela (NPS); Número de planta quebrada (NBrP); Número de plantas com acamadas (NBeP); empalhamento (St); Comprimento da espiga (EL); Diâmetro da espiga (DE); Número de espigas (EN); Prolificidade (Pr); Número de espigas doentes (EQM); Número de espigas atacadas por pragas (NEP); Peso de espiga (EW); Rendimento de grãos (YIE) e Índice de clorofila total (TCI). A análise de variância foi realizada pelo teste F com nível de significância de 5\% e também pela avaliação dos parâmetros genéticos. Em relação aos dados morfoagronômicos, a análise de variância e a análise dos parâmetros genéticos mostraram que não houve interação genótipo $x$ ambiente no que diz respeito à variabilidade genética entre as famílias em estudo. Por fim, a seleção final dos genótipos superiores foi feita com base no ranking das 40 familias mais produtivas, das quais, combinadas com os dados moleculares, foram selecionadas as 30 mais produtivas, mais tolerantes à seca e mais geneticamente diversificadas. para compor o próximo ciclo de seleção recorrente de milho visando tolerância ao estresse hídrico. Palavras-chave: diversidade genética, melhoramento interpopulacional, seleção recorrente recíproca, estresse hidrico.

\section{INTRODUCTION}

Among the environmental factors, water deficit is one of the major stresses limiting agricultural production at a global level (SILVA et al., 2011). Maize is a grain quite susceptible to this condition in the pre-flowering, flowering, and grain-filling stages, such that it cannot recover under rehydration (HERNÁNDEZ et al., 2015).

Drought tolerance in maize is a complex and composite trait. The definitions of drought tolerance and tolerance levels used mainly focused on the phenotypic manifestations of the trait (KASSIE et al., 2017). In maize systems, along with water

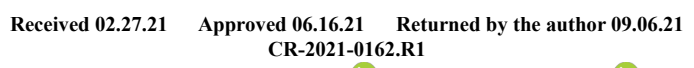


conservation and soil management, drought-tolerant maize is a key option available to farmers as a protection against drought (ALMEIDA et al., 2019; BERILLI et al., 2020).

Over $90 \%$ of the maize area grown worldwide is non-irrigated, and annual yield losses resulting from drought are estimated at approximately $15 \%$ of total yield potential. Losses are significant in tropical countries that rely on a relatively unpredictable rainy season for crop growth (ABREU et al., 2017). The study conducted by ADEBAYO et al. (2014) reported that water stress leads to lower grain yield, and losses can be as high as $80 \%$ during the flowering and grain-filling stages. Hence, there is a great need to develop methodologies to provide an alternative for the improvement of maize yield.

A tool to improve this scenario is the reciprocal recurrent selection suggested by COMSTOCK \& ROBINSON (1948), which simultaneously improed two populations. Nevertheless, such populations must be genetically distant and with high agronomic potential, thus enabling an improved open pollination population to be obtained at the end of each cycle, as well as interpopulation hybrids to obtain cultivars.

Other reciprocal recurring selection programs have also been using this selection on fullsib families of maize. The Universidade Estadual do Norte Fluminense Darcy Ribeiro has been one of these examples when started using this methodology in 1996. It has succeeded in registering and releasing, in the Ministry of Agriculture, Livestock, and Food Supply (MAPA, abbreviation in Portuguese), two maize hybrids, 'UENF506-6' and 'UENF506-11', recommended for both the northern and northwest of Rio de Janeiro State, Brazil (CUNHA et al., 2012; BERILLI et al., 2013).

Intending to improve genetic diversity studies, the use of molecular markers has made it easier to evaluate genetic diversity among lines. Molecular markers may contribute to plant breeding programs for the selection of genotypes to be used as genitors of new cultivars, for genetic diversity studies, fingerprinting, development of genetic maps, and assisted selection (MOULIN et al., 2015; BRILHANTE et al., 2021).

We genotyped the respective families of fullsiblings selected for agronomic traits of the populations Padrinho and Piranão of the IFES reciprocal recurrent selection program, with the following objectives:

i) assess the possibility of identifying the presence of little contrasting individuals between the groups, which are; therefore, of little interest for the recombination lot; ii) optimize heterotic effects in crosses between distant individuals, and iii) includ longevity in the recurring selection program by increasing the genetic variability of crossbreeding populations.

From what was described above, this research conducted a cycle of a reciprocal recurrent selection of full-sib families of maize.

\section{MATERIALS AND METHODS}

An intercross of Padrinho (semi-flint grain) and Piranão (dent grain) maize populations was performed. Crosses were carried out on prolific plants and, for each pair of plants, two self-fertilizations and two crosses were made, which were reciprocal. Thus, 64 full-sib families and 128 self-fertilized progenies $\left(\mathrm{S}_{1}\right)$ were obtained. The $\mathrm{S}_{1}$ seeds were stored in a cold chamber, and the full-sib families were used for the competition trial.

For that purpose, experiments were conducted in a randomized block design with two replicates in the two following environments: Instituto Federal do Espírito Santo-Ifes campus Alegre, located in the municipality of Alegre, in the southern region of Espírito Santo State, Brazil; and Instituto Federal do Espírito Santo-Ifes campus Itapina, in the municipality of Colatina, in the northwest part of Espírito Santo State. Each experimental unit was grown in 3.0-m long rows, spaced $1.0 \mathrm{~m}$ apart, and between plants $0.20 \mathrm{~m}$ apart. Fertilization was done according to the soil analysis and nutritional requirements of the crop following the recommendations of PREZOTTI et al. (2007). Irrigation in both environments, Alegre and Itapina, occurred every day, six to eight hours a week, until the male flowering period,;. The maize crop cycle period is the most critical regarding water stress.

For the morpho-agronomic evaluation of full-sib families, the following traits were analyzed: Male flowering (MF); Female flowering (FF); Flowering interval (IF); days for flowering (DF); Plant height $(\mathrm{PH})$; Ear height $(\mathrm{EH})$; number of plants at the Stand (NPS); Number of broken plant (NBrP); Number of bedded plants (NBeP); Strawing (St) ; Ear length (EL); Ear diameter (ED); Ear number (EN); Prolificacy (Pr); Number of diseased ears (NDE); Number of ears attacked by pests(NEP); Ear weightb (EW); Yield (YIE), estimated on the dehusked ear weight in $\mathrm{kg}$, adjusted to a projection of $10,000 \mathrm{~m}^{2}$ and 100-grain weight (W100HG).

For the Total Chlorophyll Index (TCI) for this analysis, data collection was performed in only 
one plant per plot, using the portable chlorophyll meter model Chlorophyll Meter SPAD-502PLUS, in all phenological stages. Data were obtained from readings made on the leaf related to the first ear, choosing the middle third of the leaf blade at $2 \mathrm{~cm}$ from the leaf edge, excluding the central vein. The evaluations were conducted between 8 a.m. and 10 a.m. Rainfall data for weather monitoring were collected from the following automatic stations: Estação Automática Alegre-A617 and Estação Automática Aimorés-A534 (Instituto Nacional de Meteorologia, 2019). In Itapina, the total rainfall was $104.4 \mathrm{~mm}$ and, in Alegre, $333.0 \mathrm{~mm}$ (Figure 1).

Data were submitted to analysis of variance by the $\mathrm{F}$ test at a 5\% significance level, in accordance with the model below:

$Y_{\mathrm{ijk}}=\mu+B / A_{\mathrm{k}(\mathrm{j})}+A_{j}+G_{i}+G_{\mathrm{Aij}}+\epsilon_{\mathrm{ijk}}$

in which

$\mathrm{Y}_{\mathrm{ijk}}$ : value observed in the ijk plot;

$\mu$ : overall constant;

$\mathrm{B} / \mathrm{A}_{\mathrm{k}(\mathrm{j})}$ : effect of the $\mathrm{k}$-th block within the $\mathrm{j}$-th environment;
$A_{j}$ : effect of the $\mathrm{j}$-th environment;

$\mathrm{G}_{\mathrm{i}}$ : effect of the $\mathrm{i}$-th genotype;

$\mathrm{GA}_{\mathrm{ij}}$ : effect of the interaction between the i-th genotype and the $\mathrm{j}$-th environment;

$\epsilon_{\mathrm{ijk}}$ : random error associated with the Yijk observation.

From the expected values, the following genetic parameters were obtained:

Genotypic variance: $\hat{\mathrm{o}}_{\mathrm{g}}^{2}=(\mathrm{MSG}-\mathrm{MSR}) / \mathbf{e}$

Phenotypic variance: $\hat{o}_{\mathrm{f}}^{2}=\mathrm{MSG} / \mathbf{e}$

Heritability based on the family mean:

$\mathrm{h}^{2}=\hat{\mathrm{o}}_{\mathrm{g}}^{2} / \hat{\mathrm{o}}_{\mathrm{f}}^{2}$

$\left.\mathrm{CV}_{\mathrm{g}}(\%)=\left(100 \cdot \sqrt{\hat{\sigma}_{\mathrm{g}}^{2}}\right) / \overline{\mathrm{x}}\right)$

Coefficient of genetic variation:

Variation index: $\mathrm{I}_{\mathrm{V}}(\%)=100\left(\mathrm{CV}_{\mathrm{g}} / \mathrm{CV}_{\mathrm{e}}\right)$

in which

$\mathrm{MSG}=$ mean square of genotypes;

$\mathrm{MSR}=$ mean square of residue;

$\mathrm{r}=$ replicate;

$\mathrm{e}=$ environment.

The gains from direct selection for the yield trait $\left(\mathrm{GS}_{\mathrm{dx}}\right)$ and the gains for the traits affected

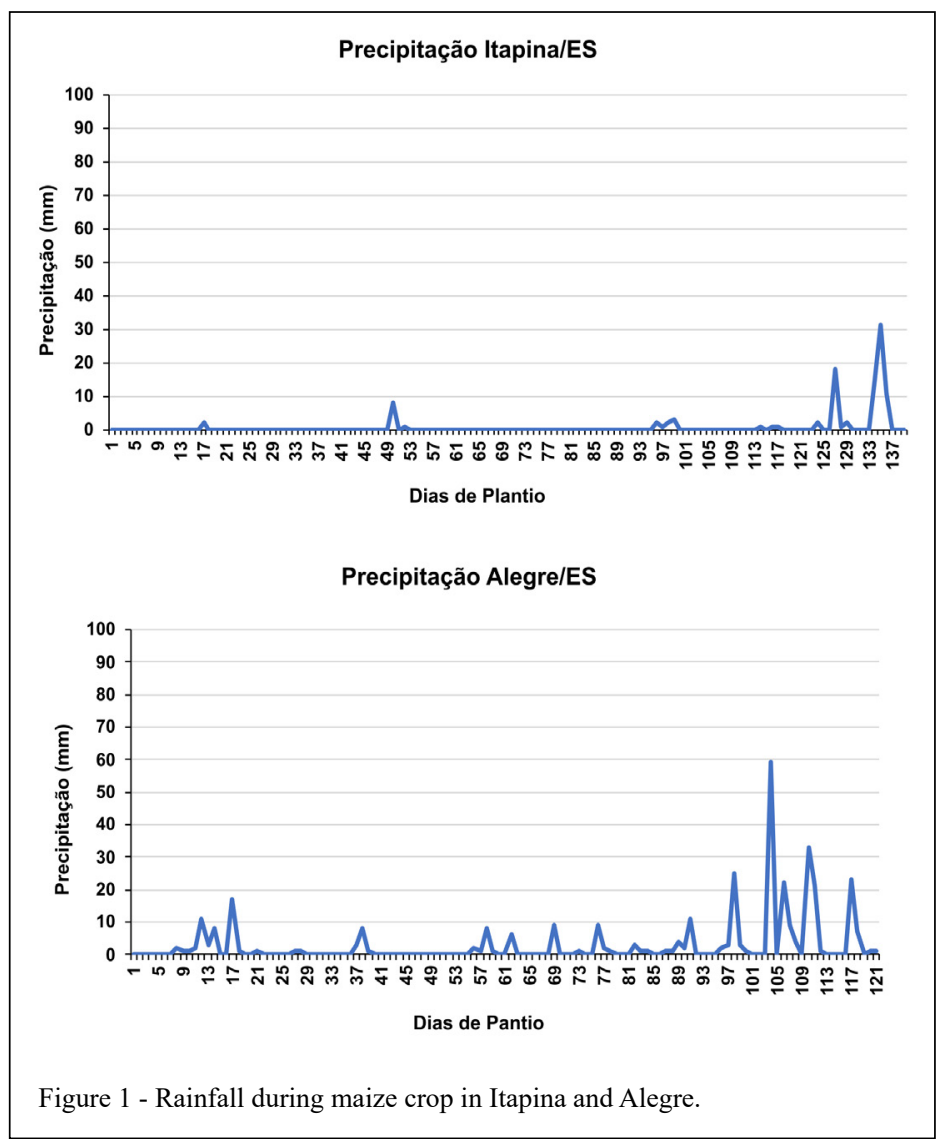

Ciência Rural, v.52, n.5, 2022. 
by direct selection in yield were estimated using the system adopted by Eberhart (1970): $\mathrm{GS}_{\mathrm{dx}}=\mathrm{DS}_{\mathrm{x}} \cdot \mathrm{p} \cdot \mathrm{h}_{\mathrm{x}}^{2}$ , being $\mathrm{DS}_{\mathrm{x}}=$ selection differential; $\mathrm{p}=$ parental control; $h_{x}^{2}=$ heritability coefficient.

An important step in the recurrent selection is the choice of populations with high agronomic potential. In this sense, based on the results of the direct selection gains, of the 64 families of full siblings evaluated, the 40 families, considered superior, were selected to submit them to 'genotyping' via ISSR markers for. Such selection was carried out in order to maximize the genetic variability in the populations worked and trying to maintain, and even expand, the genetic distance between them thus favoring heterosis by enhancing the crossing between contrasting individuals.

For 'genotyping' via ISSR markers, their respective seeds, which were stored in a cold chamber, were used for the DNA extraction. Ten seeds of each genotype were planted in five-liter pots in the greenhouse, having their leaves collected in bulk for subsequent extraction.

The material was macerated in liquid nitrogen to a fine powder. The DNA extraction was carried out according to the Doyle and Doyle protocol (1997).

After extracting the DNA, the Qubit 2.0 Fluorometer equipment quantified the samples, thus, obtaining the DNA concentrations. Subsequently, samples from the same treatment were diluted to 10 $\mathrm{ng} / \mu \mathrm{L}$, and PCRs were performed for the molecular marker test under the following condition: $25 \mu \mathrm{l}$ each sample, with $2.4 \mathrm{mM} \mathrm{MgCl}, 0.25 \mathrm{mM}$ of Tris$\mathrm{KCl} ; \mathrm{pH} 8.3 ; 0.25 \mathrm{mM}$ of each dNTP; $0.2 \mathrm{uM}$ of molecular markers; 1 U of Taq DNA polymerase; and 30 ng de DNA. For the amplification reactions, the programming was as follows: initial denaturation for $15 \mathrm{~min}$ at $94{ }^{\circ} \mathrm{C} ; 35$ cycles of $30 \mathrm{sec}$ at $94{ }^{\circ} \mathrm{C}, 30 \mathrm{sec}$ at $52{ }^{\circ} \mathrm{C}$, and $1 \mathrm{~min}$ at $72{ }^{\circ} \mathrm{C}$; and a final extension step for 7 minutes at $72{ }^{\circ} \mathrm{C}$. The reaction products were separated by agarose gel electrophoresis at $2 \%$ immersed in TBE $1 \mathrm{X}$ buffer $(89 \mathrm{mM}$ Tris base, $89 \mathrm{mM}$ boric acid, $2.23 \mathrm{mM}$ EDTA) under constant voltage $(110 \mathrm{~V})$ for 3 hours. A $100 \mathrm{bp}$ marker was used as a positive control in the staining step.

A screening of molecular markers for molecular analysis was initially conducted; among them, ten polymorphic molecular markers were selected for investigation, namely UBC $807(\mathrm{AG})_{8} \mathrm{~T}$; UBC 808 $(\mathrm{AG})_{7} \mathrm{C}$; UBC 809 (AG) ${ }_{8} \mathrm{G}$; UBC 825 (AC) $)_{8}$; UBC $826(\mathrm{AC})_{8} \mathrm{C}$; UBC 835 (AG) $)_{8} \mathrm{YC}$; UBC $855(\mathrm{AC})_{8} \mathrm{YT}$; UBC 880 (GGAGA); and UBC 890 (AC) $)_{8}$ YA.

For the analysis of ISSR markers, the gels were interpreted by the presence and absence of bands, generating a binary matrix. The complement of the Jaccard similarity coefficient was used to estimate the genetic distances between the genotypes. The genetic distances were analyzed using UPGMA (unweighted pair-group method using arithmetic average).

All the analyses were carried out using GENES (CRUZ, 2006) software system.

\section{RESULTS AND DISCUSSION}

A significant difference among the genotypes was reported for most of the traits evaluated, thereby showing that there is genetic variability in the genotypes under study; this factor is of primary importance to obtain genetic gains in breeding programs (Table 1).

When analyzing the coefficients of experimental variation, the values varied between $2.6 \%$ and $40.86 \%$. Except for the NBeP and NDE traits, which obtained values considered very high, the results demonstrate that, in general, there was an adequate experimental precision according to the classification proposed by Scapim et al. (1995).

It can be seen in the analysis of the interaction genotype $\mathrm{x}$ environment the absence of significance for the majority of the traits, showing the same performance of these genotypes in both environments. By evaluating full-sib families of maize, BERILLI et al. (2013) reported the same response as well. Hence, it may be concluded that there is a possibility of a simultaneous recommendation of superior genotypes for both the northern and southern regions of the state of Espírito Santo. The same happens with the yield trait, which is the most significant in plant breeding studies, also showing that the genotypes obtained the same behavior in both environments.

In order to select the superior genotypes in this experiment, the following traits were utilized: flowering interval (FI), ear weight (EW), yield (YIE), prolificacy (Pr), and total chlorophyll index (TCI R6), for decision making in this research since, in breeding programs, the EW, YIE, and Pr traits are the most relevant, and the FI and TCI R6 traits are secondary traits, which have been used by maize breeders for to improve drought tolerance (CAMERA et al., 2007; SILVA et al., 2010; MELO et al., 2018).

For the variable flowering interval, the genotype mean was of 2.16 days. Maize breeding programs are focused on earlier plants with a shorter flowering interval, associating these traits with greater drought tolerance (EDWARDS, 2011), added to this, the shorter flowering interval is characterized as an essential trait in genotypes more tolerant to drought, 
Table 1 - Mean squares for the traits analyzed in full-sib families of maize.

\begin{tabular}{|c|c|c|c|c|c|c|c|}
\hline \multirow[t]{2}{*}{ Traits $^{1 /}$} & \multicolumn{7}{|c|}{ ב-} \\
\hline & $\mathrm{REP} / \mathrm{ENV}$ & GEN(G) & $\mathrm{ENV}(\mathrm{E})$ & GxE & ERROR & $\mathrm{VC}(\%)$ & Mean \\
\hline FI & 0.43727 & $0.21418^{*}$ & $3.61^{\mathrm{ns}}$ & $0.15611^{\mathrm{ns}}$ & 0.14409 & 24.13 & 2.16 \\
\hline DF & 67.78906 & $9.12078^{* *}$ & $56.25^{\mathrm{ns}}$ & $4.28175^{\mathrm{ns}}$ & 3.57478 & 2.60 & 72.71 \\
\hline $\mathrm{PH}$ & 0.40738 & $0.20411^{* *}$ & $51.93004^{* *}$ & $0.11218^{\mathrm{ns}}$ & 0.1073 & 13.33 & 2.45 \\
\hline $\mathrm{EH}$ & 0.06133 & $0.09316^{* *}$ & $45.39391^{* *}$ & $0.06033^{\mathrm{ns}}$ & 0.04736 & 14.96 & 1.45 \\
\hline NPS & 4.39063 & $2.2371^{* *}$ & $105.0625^{*}$ & $1.45139^{\mathrm{ns}}$ & 1.14459 & 7.73 & 13.82 \\
\hline $\mathrm{NBrP}$ & 0.60723 & $0.29657^{* *}$ & $25.18785^{*}$ & $0.25182^{*}$ & 0.16127 & 24.42 & 2.54 \\
\hline $\mathrm{NBeP}$ & 1.01891 & $0.4572^{\mathrm{ns}}$ & $17.53516^{\mathrm{ns}}$ & $0.395^{\mathrm{ns}}$ & 0.42772 & 38.24 & 2.97 \\
\hline$\underline{\text { St }}$ & 0.03613 & $0.01404^{\mathrm{ns}}$ & $0.07223^{\mathrm{ns}}$ & $0.01619^{\mathrm{ns}}$ & 0.01677 & 17.77 & 0.05 \\
\hline EL & 1.9502 & $5.60713^{* *}$ & $240.44379^{* *}$ & $2.7568^{\mathrm{ns}}$ & 2.40099 & 11.05 & 14.01 \\
\hline ED & 0.12602 & $0.24849^{* *}$ & $15.21^{* *}$ & $0.17802^{*}$ & 0.11086 & 7.48 & 4.45 \\
\hline EN & 19.78906 & $12.85293^{\mathrm{ns}}$ & $370.5625^{*}$ & $14.81647^{\mathrm{ns}}$ & 11.92398 & 25.24 & 13.67 \\
\hline NDE & 0.01191 & $0.21124^{\mathrm{ns}}$ & $0.00191^{\mathrm{ns}}$ & $0.1639^{\mathrm{ns}}$ & 0.17215 & 40.86 & 0.78 \\
\hline NPE & 0.04062 & $0.50339^{* *}$ & $94.33266^{* *}$ & $0.41067^{*}$ & 33.8188 & 25.93 & 4.28 \\
\hline EW & 0.71852 & $0.65603^{* *}$ & $55.31641^{*}$ & $0.42069^{\mathrm{ns}}$ & 0.35629 & 30.22 & 1.97 \\
\hline YIE & 0.45488 & $0.35708^{* *}$ & $61.52441^{* *}$ & $0.23283^{\mathrm{ns}}$ & 0.19798 & 31.89 & 4649.74 \\
\hline W100HG & 38.18352 & $28.03015^{* *}$ & $307.56391^{\mathrm{ns}}$ & $10.39319^{\mathrm{ns}}$ & 12.46129 & 10.13 & 34.81 \\
\hline $\operatorname{Pr}$ & 0.21695 & $0.07912^{\mathrm{ns}}$ & $3.95016^{\mathrm{ns}}$ & $0.10547^{*}$ & 0.06933 & 26.62 & 0.98 \\
\hline TCI VT & 66.8252 & $42.7406^{* *}$ & $660.81129^{\mathrm{ns}}$ & $30.46454^{* *}$ & 20.38583 & 10.33 & 43.67 \\
\hline TCI R1 & 53.55352 & $43.02547^{* *}$ & $2080.50016^{*}$ & $31.78722^{\mathrm{ns}}$ & 22.4874 & 10.75 & 44.09 \\
\hline TCI R2 & 39.73016 & $47.7652^{* *}$ & $4346.10563^{* *}$ & $22.92912^{\mathrm{ns}}$ & 24.37405 & 11.53 & 42.81 \\
\hline TCI R3 & 56.2402 & $38.09553^{* *}$ & $2646.45941^{*}$ & $21.26211^{\mathrm{ns}}$ & 22.09139 & 10.91 & 43.04 \\
\hline TCI R4 & 38.24031 & $123.28809^{\mathrm{ns}}$ & $710.88891^{*}$ & $95.25327^{\mathrm{ns}}$ & 90.23444 & 21.84 & 43.48 \\
\hline TCI R5 & 337.0625 & $73.97356^{* *}$ & $507.37562^{\mathrm{ns}}$ & $41.13697^{\mathrm{ns}}$ & 29.54885 & 13.61 & 39.92 \\
\hline TCI R6 & 42.36254 & $43.51983^{\mathrm{ns}}$ & $7427.20785^{*}$ & $33.75642^{\mathrm{ns}}$ & 36.68349 & 16.69 & 36.28 \\
\hline
\end{tabular}

${ }^{1 /}$ Flowering interval (IF); days for flowering (DF); Plant height (PH); Ear height (EH); number of plants at the Stand (NPS); Number of broken plant (NBrP); Number of bedded plants(NBeP) ; Strawing (St) ; Ear length (EL); Ear diameter (ED); Ear number (EN); Number of diseased ears (NDE); Number of ears attacked by pests(NEP); Ear weightb(EW); Yield (YIE), estimated on the dehusked ear weight in $\mathrm{kg}$, adjusted to a projection of 10,000 $\mathrm{m}^{2}$ and 100-grain weight (W100HG); Prolificacy (Pr); TCI VT= Total Chlorophyll Index phase VT; TCI R1= Total Chlorophyll Index phase R1; TCI R2= Total Chlorophyll Index phase R2; TCI T R3= Total Chlorophyll Index phase R3; TCI R4= Total Chlorophyll Index phase R4; TCI R5= Total Chlorophyll Index phase R5 e TCI R6= Total Chlorophyll Index phase R6. ${ }^{* * *}$ Significant at $5 \%$ and $1 \%$ probability by the $\mathrm{F}$ test, respectively. ns Not significant.

since stress due to water deficit causes an increase in this interval, causing less fertilization of the ovaries and grain development, which significantly reduces productivity (PIAS et al., 2017).

The mean value obtained in the variable ear weight was of $1.97 \mathrm{~kg}$, and in the variable yield, the mean value of $4649.74 \mathrm{~kg} / \mathrm{ha}^{-1}$ was reported, which is already above the yield of the state of Espírito Santo, which is of $2,896 \mathrm{~kg} / \mathrm{ha}^{-1}$ (CONAB, 2018), even the experiment being under water deficit. Evaluating the performance of maize genotypes under water stress, Melo et al. (2018) reported a value of $4823.4 \mathrm{~kg} / \mathrm{ha}^{-1}$ for yield.

KASSIE et al. (2017) reported that ;although, farmers normally considered yield of crop varieties when making adoption decisions, they also take into consideration the suitability of such varieties to the conditions of the local environment, particularly when they live in drought prone environments. The fact that a variety has drought tolerance trait can ; therefore, be more convincing to the farmers in selecting a variety than mere exposition of the potential yield of the variety in question.

The mean value for prolificacy was 0.98 ears/ plant. PATERNIANI et al. (2015) obtained this same value. According to CÂMARA et al. (2007), some authors stated that prolificacy is one of the principal traits to be considered in breeding programs aiming water-deficit tolerance. It is because, by results obtained from studies, the heritability for prolificacy has remained constant or even increased under water stress conditions. 
By studying the relationships between water supply and grain yield for maize crop, BERGAMASCHI et al. (2006) noted that a short drought during male flowering and the beginning of grain filling affected the number of ears per plant and the number of grains per row, with the reduction in the number of ears attributed to the low synchronism caused by the water deficit. Yield attributes such as stem length, ear height, grain weight, grain yield, biomass yield and harvest index of maize are strongly affected by drought stress in the most diverse stages of plant development (SILVA et al., 2015; EL SABAGH et al., 2017).

For the variable total chlorophyll index at stage R6 (TCI R6), the mean was 36.28. Mortate et al. (2018) found values ranging from 39.17 to 56.62. The averages for SPAD decrease more rapidly under water stress conditions (CAIRNS et al., 2012), as severe water limitation can cause chlorophyll degradation in the leaves (CASTRO et al., 2014). Green intensity is linked intricately to the relative chlorophyll content in leaves, which is crucial for the photosynthetic process and; consequently, for plant yield (KHAYATNEZHAD et al., 2011).

On the basis of the analyses mentioned above, an evaluation of genetic parameters was conducted. These indicated genetic variability in the genotypes in question and also contributed to the decision making on the most promising genotypes (Table 2).

Estimates for genotypic variance $\left(\mathrm{o}_{\mathrm{g}}^{2}\right)$, phenotypic variance ( $o_{\mathrm{f}}^{2}$ ) and the interaction genotype $\mathrm{x}$ environment $\left(\mathrm{o}_{\mathrm{g}_{\mathrm{e}}}^{2}\right.$ ), coefficient of heritability $\left(\mathrm{h}^{2}\right)$, coefficients of genetic variation $\left(\mathrm{CV}_{\mathrm{g}}\right)$, variation index (Iv), means for each trait, selection gain (SG).

The genotypic variance component results from genetic differences between individuals. A high value of this component indicated wide genetic variability for the trait and plays an important role in the identification of superior genotypes (CRUZ, 2005).

The values of genotypic variance for FI and Pr were satisfactory for the traits under investigation. PATERNIANI et al. (2015) reported similar results when they evaluated 150 genotypes of full siblings of maize for drought tolerance.

For heritability, mean values were reported for EW, 45.69\%; YIE, 44.65\%; and FI, 32.72\%; and for the traits TCI R6 and PROL, the values of $15.71 \%$ and $12.39 \%$, respectively. Heritability estimates help the breeder determine the allocation of resources required to select a trait of interest and acquisition of maximum genetic gain with minimum use of time and resources (SMALLEY; et al., 2004).

In accordance with the values presented above, results obtained for the coefficient of genetic variation were $13.86 \%$ for $\mathrm{EW} ; 14.29 \%$ for YIE; $8.41 \%$ for FI; and for TCI R6 and Pr, 3.6\% and $5.0 \%$, respectively. As SEBBENN et al. (1998) stated, coefficients of genetic variation above $7 \%$ are considered high; therefore, genetic variability may also be corroborated and quantified by the coefficient of genetic variation (CVg), which expresses the magnitude of genetic variation in relation to the mean of the trait.

The value of the variation index for all traits was considered low, being necessary that it be close to or above $1 \%$ to represent a higher genetic variability (VENCOVSKY; BARRIGA, 1992). PATERNIANI et al. (2015) obtained low variation index values for most of the traits studied, many of which were also evaluated in this study. HEINZ et al. (2012) when studying progenies of half-siblings of corn reported low values only for the traits EL, ED

Table 2 - Estimates for genotypic variance $\left(\sigma_{\mathrm{g}}{ }^{2}\right)$, phenotypic variance $\left(\sigma_{\mathrm{f}}^{2}\right)$ and the interaction genotype $\mathrm{x}$ environment $\left(\sigma_{\mathrm{ge}}^{2}\right)$, coefficient of heritability $\left(\mathrm{h}^{2}\right)$, coefficients of genetic variation $(\mathrm{CVg})$, variation index $(\mathrm{Iv})$, means for each trait, selection gain (SG).

\begin{tabular}{|c|c|c|c|c|c|c|c|c|}
\hline \multirow[t]{2}{*}{ Traits } & \multicolumn{8}{|c|}{-Parameters-- } \\
\hline & $\sigma_{\mathrm{g}}^{2}$ & $\sigma_{\mathrm{f}}^{2}$ & $\sigma_{\mathrm{ge}}^{2}$ & $h^{2}$ & $\mathrm{CV}_{\mathrm{g}}(\%)$ & $\mathrm{I}_{\mathrm{V}}(\%)$ & Mean & $\mathrm{SG}$ \\
\hline FI & 0.01752 & 0.053545 & 0.00601 & 32.72 & 8.4173 & 0.3487 & 2.16 & $-2,10$ \\
\hline EW & 0.07493 & 0.1640075 & 0.0322 & 45.69 & 13.8603 & 0.4586 & 1.97 & 8,90 \\
\hline YIE & 0.03977 & 0.08927 & 0.01742 & 44.55 & 14.2973 & 0.4482 & 4649.74 & 32,50 \\
\hline $\operatorname{Pr}$ & 0.00245 & 0.01978 & 0.01807 & 12.39 & 5.0001 & 0.1878 & 0.98 & 8,00 \\
\hline TCI R6 & 1.70908 & 10.879957 & -1.46353 & 15.71 & 3.6029 & 0.2158 & 36.28 & 7,70 \\
\hline
\end{tabular}

\footnotetext{
${ }^{1 /} \mathrm{FI}=$ male and female flowering interval; EW = ear weight; YIE = yield; Pr= prolificacy; and TCI R6 = total.
} 
and EN. For the other traits evaluated, the authors found values from mediated to high.

It was verified that the selection gain for the yield trait was $32.5 \%$, which was considered high. According to CREVELARI et al. (2017) this parameter is extremely important for cherries, corresponds to the reliability with which the phenotypic value represents the genotypic value; therefore, traits with high heritability imply less influence of the environment, which increases their discriminatory power and the expected gain with selection.

By studying secondary traits relating to drought tolerance in progenies of interpopulation full siblings of maize in two environments (Campinas and Mococa, São Paulo), Paterniani et al. (2015) achieved a gain of $21.14 \%$ in this trait. BEYENE et al. (2016) when evaluating ten populations of maize test crossbreeds belonging to the CIMMYT germplasm bank with commercial checks under waterstressed and wellwatered conditions revealed genetic gain (up to $16 \%$ ) in grain yield under both drought and optimal environments. Of the 64 full-sib families evaluated, 40 families were chosen from the analysis of the morpho-agronomic data for the molecular analysis. From the obtained molecular data, the 30 families with the highest genetic variability were selected, a relevant step for prioritizing the most distinct families and for maintaining genetic variability in the next cycles of reciprocal recurrent selection for tolerance to drought in maize. Similar to this study, TARDIN et al. 2007, CUNHA et al. (2012) and BERILLI et al. (2013) used ISSR type markers to characterize the variability among the progenies of complete siblings of corn. The authors describe the relevance of using molecular markers in the analysis of progenies, since this type of descriptor has little or no environmental influence, in addition to the polymorphism generated for diversity studies.

Genetic diversity was also examined by using molecular analysis of genotypes, in which 91 bands were obtained, being 74 polymorphic bands (81.31\%) and 17 monomorphic bands (18.69\%). A mean of nine bands per molecular marker was obtained, the molecular marker (AC) $)_{8} \mathrm{YT}$ being the one that resulted in a higher number of bands, generating ten bands; the others generated from six to eight bands. The level of polymorphism reported is in line with the findings of AMARAL JUNIOR et al. (2011), who reported $89.05 \%$ of polymorphism with ISSR markers in maize, with the authors finding four to 11 bands per molecular marker applied.

The cophenetic correlation coefficient generated by the UPGMA cluster was of 0.72 , a value considered satisfactory. In the study conducted by CARGNELUTTI FILHO \& GUADAGNIN (2011), the UPGMA method was the most efficient in the grouping of maize cultivars. Furthermore, according to Cruz et al. (2014), this method considers as arithmetic means of the dissimilarity measures, which avoids quantifying the genetic divergence by extreme values between the genotypes. For this reason, among the hierarchical methods, UPGMA is the most used in the work of evaluating genetic diversity.

Thirty full-sib families were selected, which were more divergent according to the molecular analysis in order to identify the most distinct families, and further promote the maintenance of genetic variability in order to potentiate heterosis in the next cycles, and so in figure 2 the genetic divergence

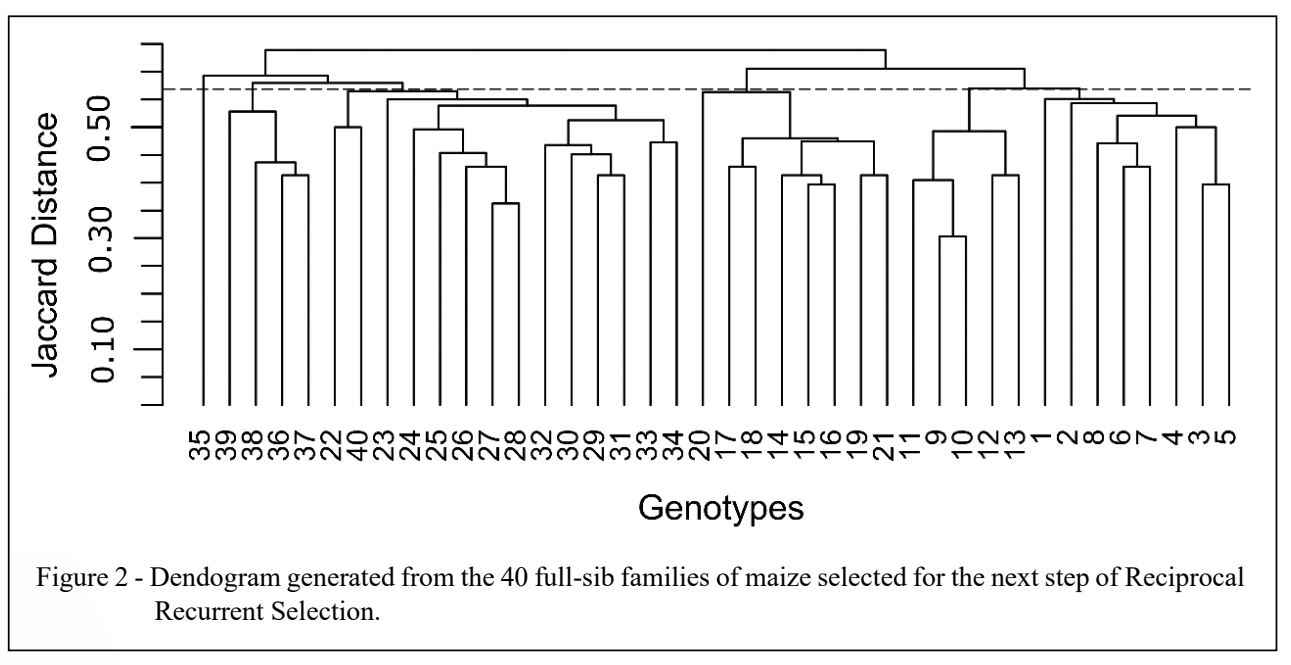

Ciência Rural, v.52, n.5, 2022. 
between the selected genotypes is presented. Knowing the genetic divergence provides parameters for the proper selection of parents, which, when crossed, result in a high heterotic effect in the progenies, maximizing the possibilities to obtain superior genotypes in segregating generations (ROTILI et al., 2012, ENTRINGER et al., 2018).

According to the authors TARDIN et al. (2007), CUNHA et al. (2012) and BERILLI et al. (2013) the evaluation of the morpho-agronomic traits is essential for the selection of maize progenies with potential interest in plant breeding and makes it possible to ascertain the genetic variability so that the longevity of a reciprocal recurrent selection program can be maintained.

\section{CONCLUSION}

It was verified through the morphoagronomic traits evaluated and through the selection gain observed that there is genetic variability to be explored in the next cycles of reciprocal recurrent selection for drought tolerance in maize progenies.

\section{ACKNOWLEDGEMENTS}

We thanks to Fundação de Amparo à Pesquisa e Inovação do Espírito Santo (FAPES) for financial support and for the scholarship given to the first author and the Coordenação de Aperfeiçoamento de Pessoal de Nível Superior (CAPES), Brasil.

\section{DECLARATION OF CONFLICT OF INTEREST}

The authors declare no conflict of interest. The founding sponsors had no role in the design of the study; in the collection, analyses, or interpretation of data; in the writing of the manuscript, and in the decision to publish the results.

\section{AUTHORS' CONTRIBUTIONS}

All authors contributed equally for the conception and writing of the manuscript. All authors revised the manuscript and approved the final version.

\section{REFERENCES}

ABREU, V. M.; et al., 2017. Indirect selection for drought tolerance in maize through agronomic and seeds traits. Revista Brasileira de Milho e Sorgo, v.16, n.2, p.287-296. Available from: <http://rbms. cnpms.embrapa.br/index.php/ojs/article/view/806>. Accessed: Aug. 10, 2020. doi: 10.18512/1980-6477/rbms.v16n2p287-296.

ADEBAYO, M. A.; et al. 2014. Genetic analysis of drought tolerance in adapted $\mathrm{x}$ exotic crosses of maize inbred lines under managed stress conditions. Euphytica, v.196, 261 p. Available from: $\quad<$ https://link.springer.com/content/pdf/10.1007/s10681- 013-1029-5.pdf>. Accessed: Jul. 22, 2020. doi: 10.1007/s10681013-1029-5.

ALMEIDA, R. N. de, et al. 2019. Evaluation of Maize Varieties for Grain Yield under Water-restricted Conditions. Journal of Experimental Agriculture International, v.39, n.4, p.1-13. Available from: $<$ https://www.journaljeai.com/index.php/JEAI/ article/view/30338/57048 > . Accessed: Jul. 15, 2020. doi: 10.9734/ jeai/2019/v39i430338.

AMARAL JÚNIOR, A. T.; et al. 2011. Assessment of genetic diversity among maize accessions using inter simple sequence repeats (ISSR) markers. African Journal of Biotechnology, v.10, n.69, p.15462-15469. Available from: <https://www.ajol.info/ index.php/ajb/article/view/97490>. Accessed: Jul. 12, 2020. doi: 10.5897/AJB10.2624.

BERGAMASCHI, H.; et al. 2006. Déficit hídrico e produtividade na cultura do milho. Pesquisa Agropecuária Brasileira, Brasília, v.41, n.2, p.243-249. Available from: <https://www.scielo.br/j/ $\mathrm{pab} / \mathrm{a} /$ GtwYt6SSLWgzsZFKgHbt36P/?lang=pt $>$. Accessed: Aug. 14, 2020. doi: 10.1590/S0100-204X2006000200008.

BERILLI, A. P. C. G. et al. 2020. Genetic Gains to Grain Yield of Maize Varieties for Small Farmers in Brazil. Journal of Experimental Agriculture International, v.42, p.1-12. Available from: <https://journaljeai.com/index.php/JEAI/article/ view/30622>. Accessed: Feb. 20, 2021. doi: 10.9734/jeai/2020/ v42i1230622.

BERILLI, A.P.C.G., et al. 2013. Response to the selection in the 11th cycle of reciprocal recurrent selection among full-sib families of maize. Acta Scientiarum, v.35, p.435-441. Available from: $<$ https://www.scielo.br/j/asagr/a/KDky695ksvMqVWMfhV9HVF $\mathrm{g} /$ ?lang=en>. Accessed: Aug. 23, 2020. doi: 10.4025/actasciagron. v35i4.17489.

BEYENE, Y., et al. 2016. Improving maize grain yield under drought stress and non-stress environments in Sub-Saharan Africa using marker-assisted recurrent selection. Crop Science, v.56, p.344-353. Available from: <https://acsess.onlinelibrary.wiley. com/doi/full/10.2135/cropsci2015.02.0135>. Accessed: Jul. 29, 2020. doi: 10.2135/cropsci2015.02.0135.

BRILHANTE, B.D.G.; et al. 2021. Phenotypic and Molecular Characterization of Brazilian Capsicum Germplasm. Agronomy, v.11, n.5. Available from: <https://www.mdpi.com/20734395/11/5/854/htm>. Accessed: May, 19, 2021. doi: 10.3390/ agronomy 11050854 .

CAIRNS, J.E., et al. 2012. Dissecting Maize Productivity: Ideotypes Associated with Grain Yield under Drought Stress and Well-watered Conditions. Journal of Integrative Plant Biology, v.54, p.1007-1020. Available from: <https://pubmed.ncbi.nlm.nih. gov/22925524/>. Accessed: Aug. 11, 2020. doi: 10.1111/j.17447909.2012.01156.

CÂMARA, T. M. M.; et al. 2007. Parâmetros genéticos de caracteres relacionados a tolerância a deficiência hídrica em milho tropical. Bragantia, Campinas, v.66, n.4, p.595-603. Available from: $\quad<$ https://www.scielo.br/j/brag/a/d6XqGK9JhW54jzXn4X QzynP/?lang=pt $>$. Accessed: Jul. 17, 2020. doi: 10.1590/S000687052007000400009 .

CARGNELUTTI FILHO, A.; GUADAGNIN, J.P. 2011. Consistência do padrão de agrupamento de cultivares de milho. 
Ciência Rural, v.41, p.1503-1508. Available from: <https:// www.scielo.br/j/cr/a/8954SNWF 8CFFQtrfLmWVQ8P/ abstract/?lang=pt $>$. Accessed: Jul. 14, 2020. doi: 10.1590/S010384782011005000116 .

CASTRO, F.A., et al. 2014. Portable chlorophyll meter (PCM502) values are related to total chlorophyll concentration and photosynthetic capacity in papaya (Carica papaya L.). Theoretical and Experimental Plant Physiology. v.26: 201-210. Available from: $<$ https://link.springer.com/article/10.1007/s40626-014-0018-y>. Accessed: May, 18, 2021. doi: 10.1007/s40626-014-0018-y.

COMSTOCK, R.E.; ROBINSON, H. F. 1948. The components of genetic variance in populations of biparental progenies and their use in estimating the average degree of dominance. Biometrics. 4: 254-266. Available from: <https://www.jstor.org/stable/3001412 >. Accessed: Jul. 14, 2020. doi: 10.2307/3001412.

COMPANHIA NACIONAL DE ABASTECIMENTO- CONAB. 2010. Available from: $<$ https://www.conab.gov.br/index.php/infoagro/safras/graos >. Accessed: Apr. 25, 2019.

CREVELARI, J. A.; et al. 2017. Prediction of genetic gains and correlations in corn hybrids for silage. Australian Journal of Crop Science, v.11, p.1411-1417. Available from: <http://www. cropj.com/crevelari_11_11_2017_1411_1417.pdf>. Accessed: Aug. 23, 2020. doi: $10.214 \overline{7} 5$ /ajcs.17.11.11.pne539.

CRUZ, C. D. 2005. Princípios de genética quantitativa. Viçosa, MG: UFV.

CRUZ, C.D. (2006). GENES Software: Version Windows: Computer application in Genetics and Statistics. Federal University of Viçosa, Viçosa.

CRUZ, C.D.; et al. 2014. Modelos biométricos aplicados ao melhoramento de plantas. v.2. n.3 ed. Viçosa: Ed. UFV.

CUNHA, K.S., et al. 2012. Full-sib reciprocal recurrent selection in the maize populations Cimmyt and Piranão. Genetics and Molecular Research, v.11: p.3398-3408. Available from: <https:// www.geneticsmr.com/articles/1886 >. Accessed: Aug. 13, 2020. doi: $10.4238 / 2012$.

DOYLE, J.J.; DOYLE, J.L. 1997. Isolation of plant DNA from fresh tissue. Focus, v.12:13-15.

EDWARDS, J. 2011. Changes in plant morphology in response to recurrent selection in the Iowa Stiff Stalk Synthetic maize population. Crop Science, Madison, v.51, p.2352-2361. Available from: $\quad<$ https://acsess.onlinelibrary.wiley.com/doi/abs/10.2135/ cropsci2010.09.0564>. Accessed: Aug. 10, 2020. doi: 10.2135/ cropsci2010.09.0564.

EL SABAGH, A, et al. 2017. Relationships between stomatal conductance and yield under deficit irrigation in maize (Zea mays L.). Journal of Experimental Biology and Agricultural Sciences v.5, p.15-21. Available from: <http://jebas.org/Jou.Exp.Bio. Agr.Sci/Vol5_17_Issue_N1/10.18006_2017.5(1).014.021.pdf $>$. Accessed: July, 1프, 2020. doi: 10.18006/2017.5(1).014.021.

ENTRINGER, G. C.; et al. 2016. Genetic gain estimates and selection of $\mathrm{S} 1$ progenies based on selection indices and reml/ blup in super sweet corn. Australian Journal of Crop Science, v.10 (n.3), p. 411. Available from: <http://www.cropj.com/ santos 1032016 411 417.pdf>. Accessed: Aug. 11, 2020. doi: 10.21475/ajcs.2016.10.03.p7248.
HEINZ, R.; et al. 2012. Seleção de progênies de meio-irmãos de milho para eficiência no uso de nitrogênio. Revista Ciência Agronômica, v.43, n.4. Available from: <https://www.redalyc. org/articulo.oa? $\mathrm{id}=195323720015>$. Accessed: Aug. 10, 2020. doi: 10.1590/S1806-66902012000400015.

HERNÁNDEZ, M.; et al. 2015. Maize water use efficiency and evapotranspiration response to $\mathrm{N}$ supply under contrasting soil water availability. Field Crops Research, Amsterdam, v.178, p.8-15. Available from: <https://www.sciencedirect.com/science/ article/pii/S0378429015001082>. Accessed: Aug. 25, 2020. doi: 10.1016/j.fcr.2015.03.017.

KASSIE, A. T.G.; et al. 2017. Modeling preference and willingness to pay for drought tolerance (DT) in maize in rural Zimbabwe. World Dev., 94 p.465-477. Available from: <https://www. sciencedirect.com/science/article/pii/S0305750X17300463> Accessed: May, 20, 2021. doi: 10.1016/j.worlddev.2017.02.008.

KHAYATNEZHAD, M.; GHOLAMIN, R. 2011. The effect of end season drought stress on the chlorophyll content, chlorophyll fluorescence parameters and yield in maize cultivars. Scientific Research and Essays, v.6, (n.25): p.5351-5357. Available from: $\quad<$ https://academicjournals.org/article/article1381399672 Gholamin\%20and\%20Khayatnezhad.pdf $>$. Accessed: Aug. 13, 2020. doi: 10.5897/SRE11.914

MELO, A. V.; et al. 2018. Desempenho agronômico de genótipos de milho submetidos ao estresse hídrico no sul do estado do Tocantins. Revista Brasileira de Milho e Sorgo, v.17(n.2), p.177-189. Available from: <http://rbms.cnpms.embrapa.br/index. php/ojs/article/view/817/1343>. Accessed: May, 20, 2021. doi: 10.18512/1980-6477/rbms.v17n2p177-189.

MORTATE, R. K., et al. 2018. Resposta do milho (Zea mays L.) à adubação foliar e via solo de nitrogênio. Journal of Neotropical Agriculture, v.5, (n.1), p.1-6. Available from: <https://core.ac.uk/ download/pdf/234766512.pdf>. Accessed: Aug. 13, 2020. doi: 10.32404/rean.v5i1.2202.

MOULIN, M. M.; et al. 2015. Construction of an integrated genetic map for Capsicum baccatum L. Genetics and Molecular Research, v.14, ( n.3), p.6683-6694. Available from: <https:// www.geneticsmr.com/articles/4597>. Accessed: Jul. 8, 2020. doi: 10.4238/2015.June.18.12

PATERNIANI, M.E.A.G.Z.; et al. 2015. Caracteres secundários relacionados à tolerância à seca em progênies de irmãos germanos interpopulacionais de milho. Revista Brasileira de Milho e Sorgo, v.14, n.1, p.130-144. Available from: $<$ http://rbms.cnpms.embrapa. br/index.php/ojs/article/view/590>. Accessed: Jul. 8, 2020. doi: 10.18512/1980-6477/rbms.v14n1p130-144.

PIAS, O. H. C.; et al. 2017. Componentes de rendimento e produtividade de híbridos de milho em função de doses de NPK e de deficit hídrico em estádios fenológicos críticos. Revista de Ciências Agroveterinárias, Lages, v.16, n.4, p.422-432. Available from: <https://www.revistas.udesc.br/index.php/ agroveterinaria/article/view/6878>. Accessed: Jul. 17, 2020. doi: $10.5965 / 223811711642017422$.

PREZOTI, L. C.; GomeS, J. A.; DadaltO, G.G.; Oliveira, J. A. de. 2007. Manual de Recomendação de Calagem e Adubação para o estado do Espírito Santo - $5^{\text {a }}$ Aproximação. Vitória - ES. SEEA/INCAPER/CEDAGRO, 305p. 
ROTILI, E.A.; et al. 2012. Divergência genética em genótipos de milho, no Estado do Tocantins. Revista Ciência Agronômica, v.43, n.3, p.516-521. Available from: <https://www.scielo.br/j/ rca/a/zzn4DfJQ7rV6BTcQ57SkHcB/?lang=pt >. Accessed: Aug. 11, 2020. doi: 10.1590/S1806-66902012000300014.

SCAPIM, C. A.; et al. 1995. Uma proposta de classificação dos coeficientes de variação para a cultura do milho. Pesquisa Agropecuária Brasileira, Brasília, v.30 (n.5): p.683-686. Available from: $<$ https://seer.sct.embrapa.br/index.php/pab/article/ view/4353>. Accessed: Aug. 19, 2020.

SEBBENN, A. M.; et al. 1998. Parâmetros genéticos na conservação da cabreúva - Myroxylon peruiferum L.F. Alemão. Scientia Forestalis, Piracicaba, n.53, p.31-38. Available from: $<$ https://www.ipef.br/publicacoes/scientia/nr53/cap3.pdf $>$. Accessed: Aug. 24, 2020

SMALLEY, M.D.; et al. 2004. Estimation of heritability in maize by parent-offspring regression. Maydica, Bergamo, v.49, p.221-229. Available from: <https://agris.fao.org/agris-search/ search.do?recordID=IT2005602168>. Accessed: Aug. 22, 2020.

SILVA, F. A.; et al. 2015. Milho para ensilagem cultivado nos sistemas de plantio direto e convencional sob efeito de veranico. Semina: Ciências Agrárias, v.36, n.1, p.327-340. Available from: <http://www.uel.br/revistas/uel/index.php/ semagrarias/article/view/14989>. Accessed: Aug. 25, 2020. doi: 10.5433/1679-0359.2015v36n1p327.

SILVA, M. A. V.; et al. 2010. Época de semeadura do milho para a região de Sete Lagoas, $\mathrm{MG}$, baseada na probabilidade de ocorrência de períodos secos e chuvosos. Ceres, v.57, n.4. Available from: $<$ https://www.scielo.br/j/rceres/a/34wR3xTMQB5 hqhd3FJDNj5b/?lang=pt>. Accessed: Aug. 18, 2020. doi: 10.1590/ S0034-737X2010000400003.

Silva, M. A.; et al. 2011. Melhoramento para eficiência no uso da água. In: Fritsche-Neto, R.; Borém, A. (Ed.). Melhoramento de plantas para condições de estresses abióticos. Visconde do Rio Branco: Suprema, p.127-149.

TARDIN, F. D.; et al. 2007. Selection index and molecular markersin reciprocal recurrent selection in maize. Crop Breeding and Applied Biotechnology, Londrina, v.7, p.225-233. Available from: $<$ https:// ainfo.cnptia.embrapa.br/digital/bitstream/item/66410/1/Selectionindex.pdf>. Accessed: Jul. 26, 2020.

VENCOVSKY, R.; BARRIGA, P. 1992. Genética biométrica no fitomelhoramento. Ribeirão Preto: Sociedade Brasileira de Genética. 